\title{
How Farmers Conceive and Cope with Megatrends: The Case of Finnish Dairy Farmers
}

\author{
Susanna Lahnamäki-Kivelä ${ }^{1, *}$ and Tuomas Kuhmonen ${ }^{2}$ \\ 1 Department of Economics and Management, University of Helsinki, 00014 Helsinki, Finland \\ 2 Finland Futures Research Centre, University of Turku, 20014 Turku, Finland; tuomas.kuhmonen@utu.fi \\ * Correspondence: susanna.lahnamaki-kivela@helsinki.fi
}

Citation: Lahnamäki-Kivelä, S.; Kuhmonen, T. How Farmers

Conceive and Cope with Megatrends

The Case of Finnish Dairy Farmers.

Sustainability 2022, 14, 2265. https://

doi.org/10.3390/su14042265

Academic Editor: Antonio Boggia

Received: 27 November 2021

Accepted: 11 February 2022

Published: 16 February 2022

Publisher's Note: MDPI stays neutral with regard to jurisdictional claims in published maps and institutional affiliations.

Copyright: (c) 2022 by the authors Licensee MDPI, Basel, Switzerland. This article is an open access article distributed under the terms and conditions of the Creative Commons Attribution (CC BY) license (https:// creativecommons.org/licenses/by/ $4.0 /)$.

\begin{abstract}
Megatrends (urbanization, digitalization, globalization, climate change, etc.) are mainstream developments that affect most economic activities. These megatrends have varying incidences and impacts on individual entrepreneurs and enterprises, also in farming sector. A farmer can either ignore or try to adapt to or benefit from megatrends. This reaction depends on many things: individuals' futures orientation, management practices, business strategy, sunk costs, the life cycle and type of business, for example. The study explores the association between eight common megatrends and business strategies among a sample of Finnish dairy producers. The analysis is based on survey data from the year 2019 ( $n=135)$ collected among a major Finnish dairy industry co-operative's contract producers. The respondents evaluated the expected impact of the megatrends on their own business within the next 10 years with 5 -point Likert-type scale $(-2 \ldots+2)$. K-means cluster analysis was utilized to uncover a few basic settings in the association between megatrends and farmers behaviours. After trying out several numbers of clusters, a distinctive three cluster solution was found. Additionally, cluster member profiles were framed with farmers' Likert -scale responses. The analysis indicates that dairy farmers differ in their observation of megatrends. The results confirm that some of the farmers more or less ignore the common megatrends, whereas some other farmers adapt to or benefit from the common megatrends. Supporting farmers' futures consciousness will strengthen their capacities of coping in the changing business environment.
\end{abstract}

Keywords: agriculture; megatrends; futures; k-means clustering; anticipation; farm management

\section{Introduction}

The farming sector confronts various challenges, many of which have turned into external change drivers. On a farm level, farm managers need to cope with these. Previous research focusing on the future and farm management has explored how farmers cope with policy reforms [1], market changes [2], and climate change [3,4]. Megatrends are mainstream developments that arise from environmental, social, and technological drivers and affect policies and markets and, thus, also farms and farmers. Despite this, a holistic understanding of farmers' perceptions of the impacts of the megatrends is scarce. This paper aims to give a glimpse into this topic using the case of Finnish dairy farms. This study explores Finnish dairy farmers' judgements of the impact of selected megatrends to their business on a farm level and how these farmers build adaptative capacity in the long run. The results present profiles of Finnish dairy farmers regarding the impact of megatrends, futures consciousness, and farm management practices.

Farm businesses' specific characteristics (e.g., biological and geographical characteristics) influence business management [5] alongside the social demands of, e.g., local food [6]. Food systems are global, and Finland is a part of the global markets. Due to this, Finnish primary production confronts globalization and the common sociocultural changes. Furthermore, consumers influence farming indirectly, by enhancing market demand for sustainable actions in agriculture [7]. Additionally, global consumer demand affects not only the markets, but also policy reforms. 
Pouru et al. [8] state that business units have complex environments, and they face turbulence caused by changes in their operating environments. In agriculture, the complexity is arising from, e.g., climate issues and administrative regulations [9]. In most businesses, managers and leaders are forced to adopt new methods and tools to ensure business survival [10]. Similar challenges exist for farmers, too. Dairy farmers are manifesting a conversion from milk producers to business unit managers and CEOs, along with the evolution toward fewer and larger farms. While the structural change promotes farm expansion, the farmers need to focus more on managerial tasks [11]. These management challenges require strong competence in strategic decision-making, complemented with an entrepreneurial attitude [12].

Farms' strategies relate to previous decisions. Expansion investments tend to manifest path dependency in farm development [13]. In the medium and long term, change drivers may affect business opportunities. Change drivers can have either a positive or negative impact on business units. The concept of futures consciousness can depict farmers' ability to cope with turbulent operating environments. Futures consciousness in the farming sector may assist to understand farm level strategic decision-making. Farmers' ability to evaluate and build an adaptive business strategy becomes a necessity, due to the increased turbulence in the business environment and accelerating structural change across Europe. Business survival requires long term planning with a sufficient planning horizon. Poli [14] and Vecchiato [15] consider strategic planning as a major challenge due to the increasing uncertainty in the business environment. Generally, strategy implies the establishment of an adequate fit between internal and external factors. Internal factors are related to the farm location along with farm specific and farmer specific characteristics [16]. The strategy process is bound to history, the current situation, and the goals and visions of future. However, the future is unknown and adaptive adjustments of the business strategy may provide a means to survive in the turbulent business environment [17].

Evaluation of the business environment can be performed at different levels. According to Lee et al. [18], the business environment has three levels: the external farm environment level, operational farm management level and farm management level.

A farmer lacks the power to influence elements of the external environment [18]. European agriculture is featured in the Common Agriculture Politics (CAP) of the European Union, where goals, means, and boundaries are given for the farmers for long periods. Megatrends are major driving forces in the external environment. Megatrends, such as climate change, digitalization, globalization, socio-cultural change, and technological development, have left their imprint across the globe. Finnish agriculture is no exception. For example, climate change is influencing farming globally, through changing weather conditions and modified risks [19]. Finland, due to its northern geographical location, may also benefit from the changing climate [19]. Another major force, digitalization, has a practical manifestation in precision agriculture, with new tools, for example, for cattle housing management, soil sensing, and improved food security [20]. Policies and other macro-scale forces in the external environment may cause uncertainties but also open up opportunities [21].

The second level in Lee's classification is the operational farm management level. The operational farm management level includes markets [18]. In the Finnish dairy markets, farmer owned co-operatives have a dominant role in the whole milk value-chain from raw milk refinement to exports. These co-operatives are tools for the dairy farmers to tackle market risks. Despite this risk management action, the market situations are not defined by individual dairy farmers.

The third level, the farm management level, is the part of the environment where the farmer has the most control [18]. On the farm management level, the individual dairy farmer has the power to run the strategic and operational management. These three levels place the farmers in a situation where adaptability and reactivity to different changes may determine the farms' economic success. To decrease the uncertainties, the dairy farmers may try to gain knowledge and an understanding of the possible futures of his/her business 
environment, estimate the possible outcomes of various strategies, and make decisions at the farm management level after thorough consideration.

The specific business environment evaluation process can be framed with the futures consciousness concept [22]. The concept has been specified in several ways. Sharpe and Hodgson [23] make a distinction between short term managerial, mid term entrepreneurial, and long term visionary modes of anticipatory awareness. The futures consciousness concept generally describes both, individuals' and organizations' capacities of considering future consequences "openly assessing alternative courses" [24] (p. 11). According to Ahvenharju et al. [24], futures consciousness has five dimensions: time perspectives, agency beliefs, openness to alternatives, systems perceptions, and concern for others. Traditionally in decision-making and foresight, time has three dimensions: past, present, and future [25]. The agency beliefs of the futures consciousness concept expresses the role of individuals in shaping the future [23]. On the farm management level, this relates to strategic actions by the farmers, in which they respond to or anticipate changes in business environments. The third dimension of the concept is openness to alternatives. This illustrates the ability to overcome challenging situations and break path dependency [24]. Systems perceptions in the futures consciousness concept includes the capacity to understand the complexity of societies and the actions of societies [24]. Lastly, the fifth element of the concept is concern for others, i.e., bringing in "values, morals and ethical thinking" [24]. These themes are strongly related to livestock farming and under heated public debate. This debate may affect policies as well as farming strategies and practices.

Dairy farming asks for heavy capital investments and thus requires a long range planning approach. Consequently, farmers with a high futures consciousness could possibly find more opportunities in the changing business environment, when compared to farmers who lack interest in the future. Futures consciousness can also decrease the vulnerability of the farm business. Farmers' vulnerability is a widely studied topic [26,27], aiming to understand how farmers can improve their ability to survive in complex environments. In other words, how they can build adaptive capacity and benefit from opportunities.

Farmers' ability to recognize opportunities may be linked to the farmers' strategic choices [12]. Farmers are individuals who make decisions according to their values and business management goals and capabilities. However, in these decision-making processes, the farmers also confront the driving forces of the macro-environment, which create threats and opportunities [21]. When the decisions at hand are long lasting, farmers often justify their decisions according to their personal attitude toward the future. Indeed, e Cunha et al. [28] emphasize the need of "patience and courage" while making strategic decisions. While the future may bring undesirable occurrences, courage is needed to confront the possible fear of future and patience to work for a desirable future for a long period of time [28]. Teigen and Brun (p. 114, [29]) note that people with negative expectations tend "to engage in preventive behaviour" while focusing on preferable outcomes; the role of negative outcomes then diminishes during the decision-making. With a positive mindset, a person has an orientation toward opportunities [29].

Previous studies, e.g., Methorst et al. [12], found Dutch dairy farmers' perceptions of opportunities to translate into three options: (1) diversification, (2) exit dairy farming, or (3) the expansion of milk production. While the farmers have their personal mindsets, they also perceive and act in a specific situation with different strategies [12]. Regarding this, it is relevant to assume that their anticipation toward megatrends will vary. Additionally, there appears to be variation in how farmers are able and willing to identify and exploit opportunities arising from the changes in the business environment. The strategic decisionmaking of each farmer is framed with the unique boundaries and constraints of the farm business situation [12].

This paper aims to add understanding on how the impact of certain mainstream developments-megatrends-are being assessed to affect farm business over the next ten years by Finnish dairy farmers. Proposals for education, counselling, and policies to 
support farmers' adaptation to the complex and changing business environment can be suggested through better understanding of farmers' future perceptions and judgements.

In the following chapters, we explore how Finnish dairy farmers assess common megatrends. Based on this, profiles of farmer groups (clusters) are reconstructed and differences in the visions, goals, and plans for the future, as well in the futures and management orientations between the groups, are discussed.

\section{Materials and Methods}

The empirical research of this study builds on a quantitative survey dataset with responses from 135 Finnish dairy farmers. The following results provide an overview of the Finnish dairy farmers, as sample is small and slightly biased toward young farmers and large farms, implying that the results are indicative and not directly generalizable to the whole base population. Overall, there were 5727 farms with dairy farming as a main production line in Finland in 2019, when the survey was conducted [30]. In ten years, the number of dairy farms in Finland has decreased from 10,205 in 2010 to 5015 in 2021 [30]. Concomitantly, the herd size has almost doubled in a decade [30]. Comparison of Finnish national statistics and sample in herd size classes is presented in Table 1.

Table 1. Respondents' herd sizes and Finnish national herd size statistics by 1 May 2019, including all farms with dairy cattle, including farms where other production lines are the main income source.

\begin{tabular}{ccccc}
\hline & Sample & & Finnish Statistics * \\
\hline $\begin{array}{c}\text { Herd Size, } \\
\text { Milking Cows }\end{array}$ & $\begin{array}{c}\text { Number of } \\
\text { Observations }\end{array}$ & $\%$ & $\begin{array}{c}\text { Number of } \\
\text { Observations }\end{array}$ & $\%$ \\
\hline $1-9$ & 0 & $0 \%$ & 526 & $8 \%$ \\
$10-14$ & 0 & $0 \%$ & 527 & $12 \%$ \\
$15-19$ & 4 & $3 \%$ & 755 & $22 \%$ \\
$20-29$ & 11 & $8 \%$ & 1369 & $15 \%$ \\
$30-39$ & 26 & $19 \%$ & 935 & $8 \%$ \\
$40-49$ & 19 & $14 \%$ & 520 & $16 \%$ \\
$50-74$ & 47 & $35 \%$ & 992 & $4 \%$ \\
$75-99$ & 9 & $7 \%$ & 269 & $5 \%$ \\
$100-149$ & 14 & $10 \%$ & 306 & $1 \%$ \\
$150-199$ & 4 & $3 \%$ & 83 & $1 \%$ \\
$200-299$ & 1 & $1 \%$ & 54 & $0 \%$ \\
$300-$ & 0 & $0 \%$ & 14 & $100 \%$ \\
\hline Total & 135 & $100 \%$ & 6350 & \\
\hline
\end{tabular}

* National Resources Institute Finland, 2021.

Objective of the survey was profiling of dairy farmers in terms of their assessment of how contemporary megatrends affect their farm businesses. The survey design was started by analysis of previous studies on farm management and foresight. The survey form did undergo several revisions and commenting rounds among agricultural economists and dairy farmers. The final questionnaire included, first, questions about the respondents' demographic and farm information: gender, education level, age, entrepreneurial experience, herd size, amount of arable land, and annual turnover volume (Table 2). Second, personal values towards farming were captured by a 5 -point Likert-scale $(1=$ totally disagree ... 5 totally agree). Likert-scale was chosen as it provides versatile options for the data analysis. Additionally, Likert-scales are commonly used to measure attitudes, prospects, and tendencies [31-33]. Third, assessment of the impacts of eight common megatrends' on the farm businesses in the next ten years was also captured by a 5-point Likert-scale (Table 3). To gain more insights into the dairy farmers' aims, the survey consisted of binary questions (yes/no) concerning existing managerial goals, management tools, and aims for farm business development. The data made it possible to form clusters based on the judgements of the impacts of the megatrends and to study profiles of the farmers in the clusters. The questions are presented in the following chapter with the results. 
Table 2. Descriptives of the sample.

\begin{tabular}{lcc}
\hline Variable & Mean Value & SD * \\
\hline Age and experience: & 43.5 & \\
Age, years & 16.21 & 9.921 \\
Entrepreneurial experience, years & $n$ & \% of Sample \\
\hline Variable & & \\
\hline Gender and education: & 77 & 57.0 \\
Female & 57 & 42.2 \\
\hline Male & 1 & 0.7 \\
Not specified & 1 & 0.7 \\
Education level: & 33 & 24.4 \\
No vocational education & 10 & 7.4 \\
Vocational degree in agriculture & 29 & 21.5 \\
Vocational degree in another field & 45 & 33.3 \\
College degree in agriculture & 17 & 12.6 \\
Bachelor's degree in agriculture & 135 & 100.0 \\
Master's degree in agriculture & & \\
Total & & \\
\hline
\end{tabular}

* $\mathrm{SD}$ = standard deviation.

Table 3. For the question "How do you see the following megatrends influencing your dairy farm business in coming ten years?" farmers received explanation of each of the megatrends in the questionnaire. The responses were given with a 5-point Likert -scale responses of -2 (great negative influence) to 2 (great positive influence).

\begin{tabular}{|c|c|}
\hline Megatrends & Description \\
\hline Climate change & $\begin{array}{l}\text { Changes in the global climate systems due to human } \\
\text { activities [34]. Climate change is influencing nature, } \\
\text { humans, and organizations [35]. Global warming will affect } \\
\text { in multiple ways living on the Earth [36]. }\end{array}$ \\
\hline Digitalization & $\begin{array}{l}\text { Increase in the data transfer between humans and } \\
\text { machinery. Automation of the processes and services } \\
\text { changes the value creation [37]. }\end{array}$ \\
\hline Urbanization & $\begin{array}{l}\text { Human populations concentrate in the urban areas, cities, } \\
\text { and towns [38]. }\end{array}$ \\
\hline Globalization & $\begin{array}{l}\text { Phenomenon that promotes and increases international } \\
\text { connections and networks in businesses, economics, and } \\
\text { policies. Increases the connections of business actors across } \\
\text { countries and enhances specialization [39]. }\end{array}$ \\
\hline Technological development & $\begin{array}{l}\text { Development and adoption of new technologies affects how } \\
\text { societies, businesses and individuals operate [36]. }\end{array}$ \\
\hline Socio-cultural change & $\begin{array}{l}\text { Third sector operators are becoming important actors in the } \\
\text { provision of public services [36]. }\end{array}$ \\
\hline $\begin{array}{l}\text { Science and knowledge } \\
\text { relation change }\end{array}$ & $\begin{array}{l}\text { Open science and new ways of utilization of data increase } \\
\text { the amount of knowledge. Individuals can contribute more } \\
\text { to knowledge production [36]. }\end{array}$ \\
\hline Health and well-being & $\begin{array}{l}\text { Lifestyle related diseases are increasing, simultaneously, } \\
\text { development of medical technology extends lifetime [36]. }\end{array}$ \\
\hline
\end{tabular}

The web survey link was available for the dairy farmers on the intranet of a leading Finnish dairy co-operative during February-March 2019. This dairy industry operator purchases raw milk from $80 \%$ of the Finnish dairy farms across the country and all these farms were included in the base population. Research aim was provided in the cover sheet of the survey. However, the survey was voluntary and resulted in a limited set of accomplished survey forms, despite the anonymity of the responses.

The survey appealed to younger than average farmers (43.5 years, compared to the national average of 49 years in 2019) [30]. Additionally, the respondents had 60 milking 
cows, which is significantly above the national average and indicates general growth and modernization orientation. A remarkable share of respondents, $67 \%$, had a bachelor's or master's degree in agriculture. Share of women among the respondents was slightly higher than their share in family labor on dairy farms ( $57 \%$ vs. $40 \%)$. Given these biases, the respondents represented future farmers better than contemporary farmers.

In order to distinguish between different assessments of the impacts of the megatrends, k-means clustering was employed. K-means clustering is a widely used clustering method [40]. The cluster analysis was employed to explore if the dairy farmers had distinct evaluations of the impacts of the megatrends on their business prospects. Cluster analysis aims for identification of underlying groups in a larger data set [41] and it is a nonhierarchical method where the number of clusters is set before the calculation [42]. In k-means clustering, the original observations are iteratively grouped into the nearest group centroid [41,42]. The value added of cluster analysis is simplification of the data, as the patterns hidden in the data can be revealed [41]. The k-means iterative partition process aims to minimize the square-error [43].

The data analysis began with transforming the original 5-point Likert-scale responses to the question "How do you see the following megatrends influencing your dairy farm business in the coming ten years?" (Table 3) to standardized scores (i.e., z-scores). Z-score reveals comparison of the observations and describes the raw scores' distance and direction from the mean [44]. Z-scores are calculated with Equation (1), where $x$ is value of the observation, $\mu_{x}$ mean and $\sigma_{x}$ is standard deviation $[44,45]$.

$$
z=\frac{x-\mu_{x}}{\sigma_{x}}
$$

The benefit of the z-scores lies in their ability to strengthen the values of the original scores, making it possible to evaluate standardized scores on the same scale [46].

After calculating the z-scores, the analysis continued to the k-means clustering, where cluster solutions of 3,4 and 5 clusters were tested. After preliminary analysis of all these alternative cluster solutions, the 3-cluster solution was chosen for profiling the clusters as the most logical representation of the profiles. It differentiated the assessments of the impacts of the megatrends in a logical way and produced clusters that had meaningful differences in the visions, goals and plans for the future, as well in the futures and management orientations between the clusters, as explained in the results. The cluster analysis is sensitive to the researchers' interpretation as the researchers choose the final cluster solution after studying several alternatives; in this case, distinctive, coherent, and logical clusters were used as the selection criteria.

\section{Results}

The purpose of the analysis was to discover potential clusters among the dairy farmers based on their assessments of the impacts of common megatrends on the farming business. The analysis resulted in three clusters. There were 45 cases in Cluster I, 28 cases in Cluster II, and 61 cases in Cluster III. The results are the starting point for the profiling of farmers in terms of their futures orientation, goals, and farm management practices. Selected three-cluster solutions and profiles of the clusters in terms of impact of the megatrends is illustrated in Figure 1. The three clusters have distinctively different profiles, which are described next.

\subsection{Farmers' Assessment of the Megatrends}

The three groups of farmers differed significantly in the assessment of the impacts of the megatrends. Farmers in Cluster I considered megatrends generally positively, farmers in Cluster II had varying positions on specific megatrends, while farmers in Cluster III considered megatrends generally negatively. Farmers in Cluster I considered the impacts of all megatrends - excluding urbanization and globalization — to be positive. They especially 
conceived the progress of science as well as health and wellbeing to be beneficial for business prospects.

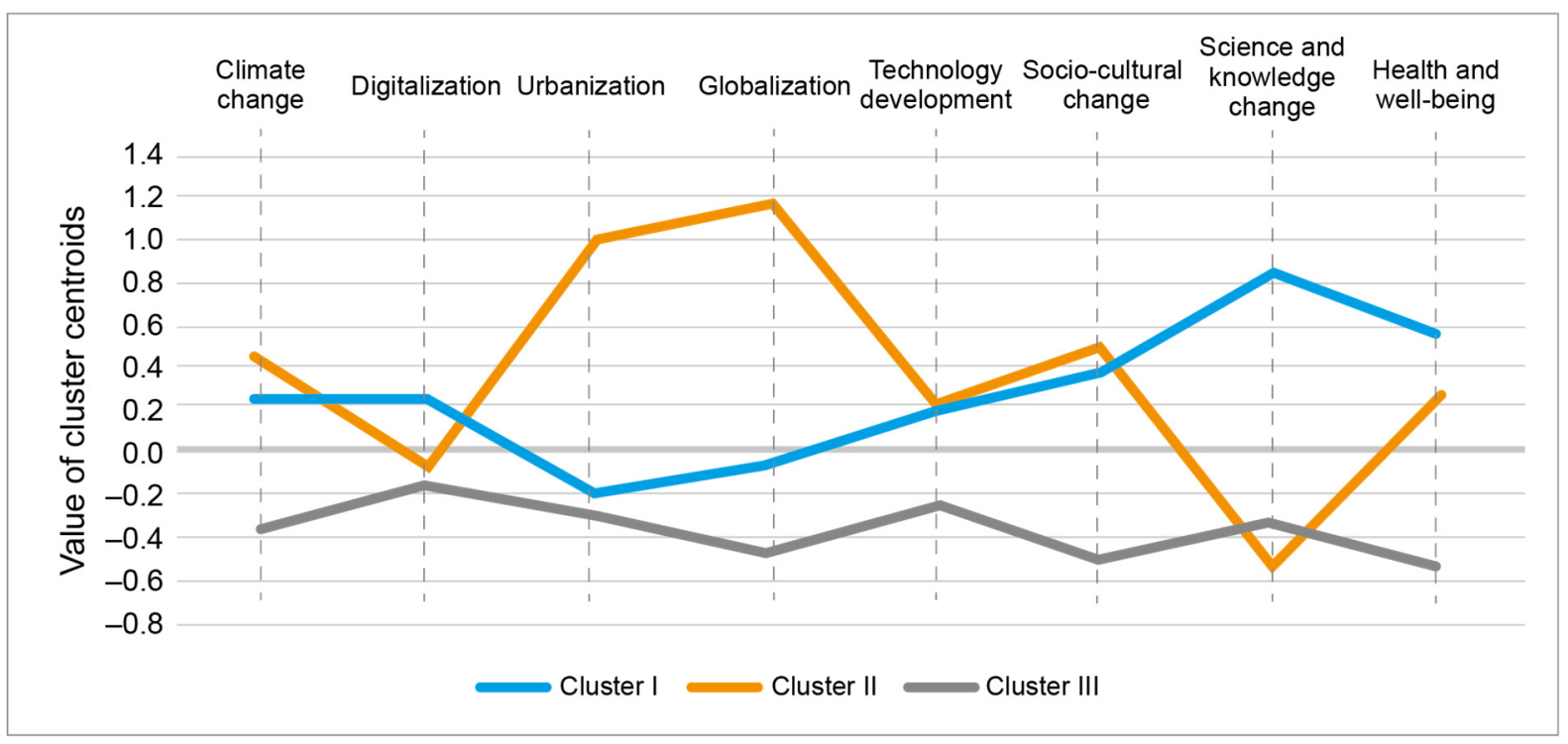

Figure 1. The three-cluster solution of farmers based on their evaluation of the impacts of megatrends on their business during the next ten years; the lines describe cluster centroids.

In Cluster II, the farmers had diverse assessments of the impacts of the megatrends. These farmers considered globalization and urbanization to clearly favor their businesses, accompanied by sociocultural change, climate change, technology as well as health and wellbeing. Only digitalization and, especially, the progress of science were expected to have a negative impact on the business futures.

Farmers in Cluster III were not expecting any of the megatrends to have a positive impact on their businesses. Instead, their expectations are generally negative. The most unfavorable trends were assessed to be health and wellbeing, sociocultural change, and globalization.

In the following sections, profiles of the three clusters are reported more thoroughly in terms of demographic and farm characteristics, visions, goals, plans for the future as well as futures and management orientations.

\subsection{Farm Management Differences among Clusters}

It is notable that there were no significant differences between the clusters in the demographic or structural variables (Table 4). These results partly reflect the skewness and small size of the sample. Differences between Clusters I and II are insignificant in terms of farm size, milk yield per cow or age of the farmer, whereas Cluster III is defined by large farm size.

The lack of differences in the physical and structural indicators hints that the cluster profiles are manifestations of differences in the "soft" factors: objectives, attitudes, orientations, competencies, and practices. Relatedly, the futures orientation of the farmers in Cluster III is shorter than in the other clusters.

In the survey, the farmers responded to binary (yes/no) questions concerning whether they had fixed visions, goals, and plans for the farm development. The options were not exclusive, meaning that a farmer could choose several options. The differences between the clusters are presented in Figures 2-4. 
Table 4. Descriptive of the clusters: physical indicators and futures orientation.

\begin{tabular}{lcccccc}
\hline & \multicolumn{2}{c}{ Cluster I } & \multicolumn{2}{c}{ Cluster II } & \multicolumn{2}{c}{ Cluster III } \\
\hline Attribute & Mean & SD & Mean & SD & Mean & SD \\
\hline Farmers' age, years & 43.89 & 9.93 & 44.14 & 10.01 & 43.10 & 9.78 \\
Years as a farmer & 15.11 & 9.15 & 17.36 & 9.13 & 16.21 & 9.67 \\
Futures orientation in years & 12.22 & 10.89 & 12.79 & 7.05 & 11.10 & 7.17 \\
Education level * & 4.00 & 1.37 & 4.14 & 1.33 & 3.90 & 1.47 \\
Own field in hectares & 53.72 & 31.04 & 57.32 & 35.80 & 66.40 & 42.07 \\
Number of milking cows & 54.63 & 31.49 & 53.96 & 27.35 & 68.85 & 40.59 \\
Average annual milk yield per cow & 9943.67 & 922.63 & 9662.79 & 1235.24 & $10,117.95$ & 1102.68
\end{tabular}

* 1 = no vocational education, 2 = vocational degree in agriculture, 3 = vocational degree in other field $4=$ college degree in agriculture, $5=$ bachelor's degree in agriculture, $6=$ master's degree in agriculture. $\mathrm{SD}=$ standard deviation.

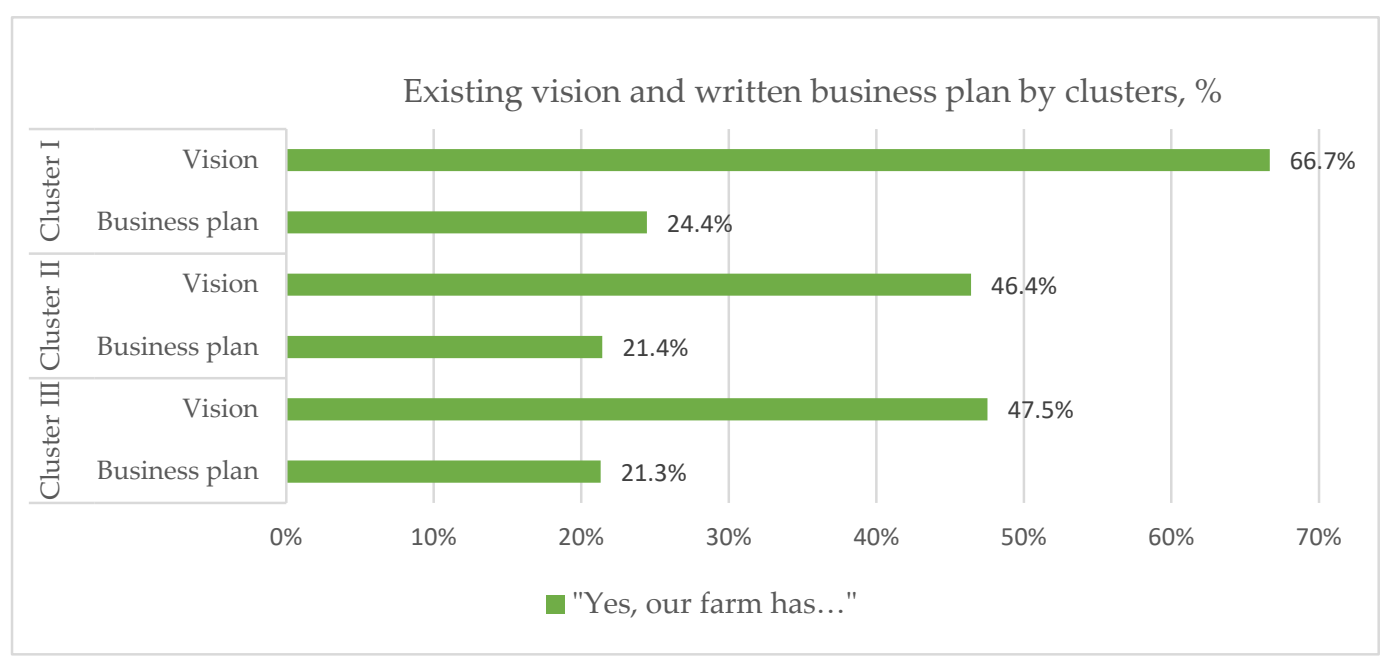

Figure 2. Share (\%) of farmers responding "yes" to following questions: "Our farm has a vision (yes/no)" and "Our farm has a written business plan (yes/no)". Missing three observations in Cluster I and missing one observation in Clusters II and III.

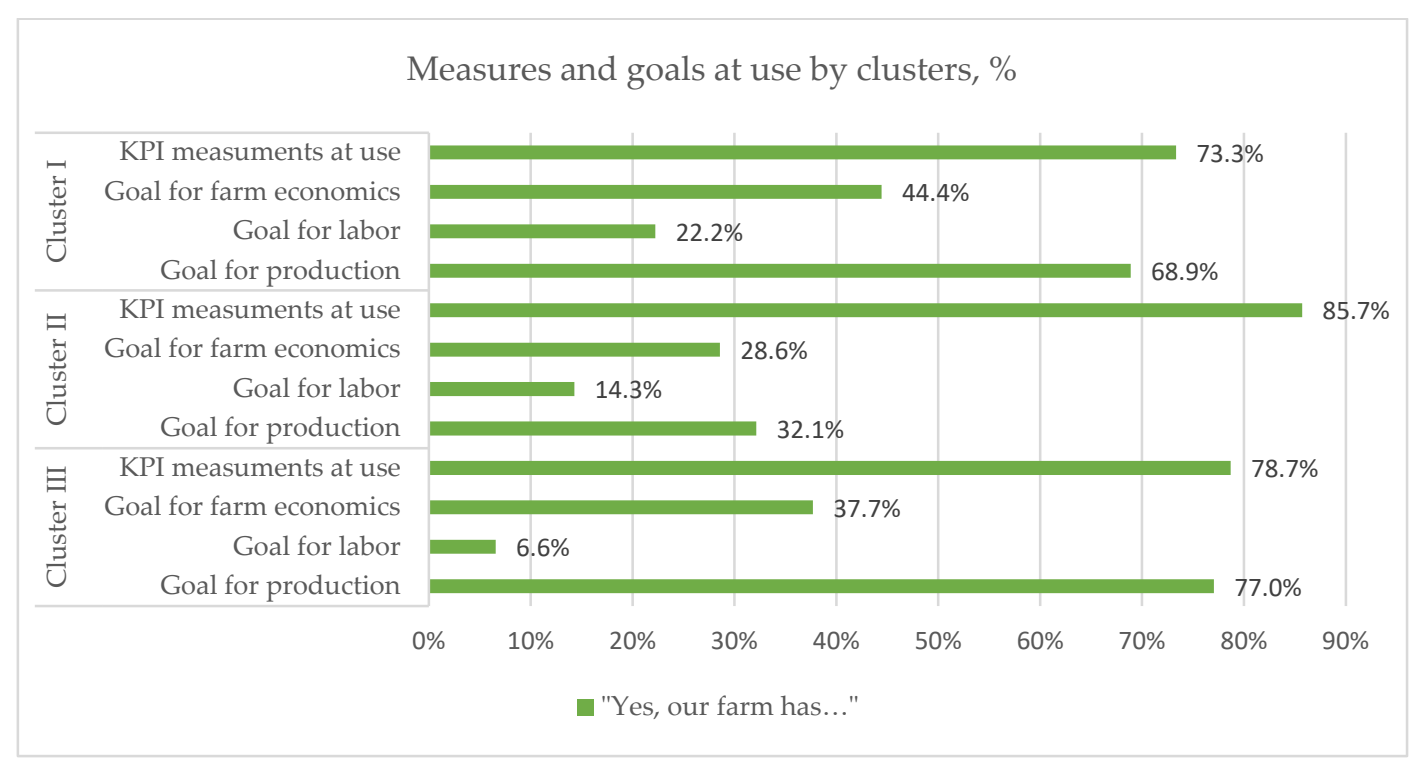

Figure 3. Share (\%) of farmers responding, "yes" to following questions: "Our farm uses KPIs (yes/no)", "Our farm has goal for the business economics (yes/no)", "Our farm has goal for the labor productivity (yes/no)", and "Our farm has goal for the milk production (yes/no)". Missing three observations in Cluster I and missing one observation in Clusters II and III. 
Existing plans for farm development, \%

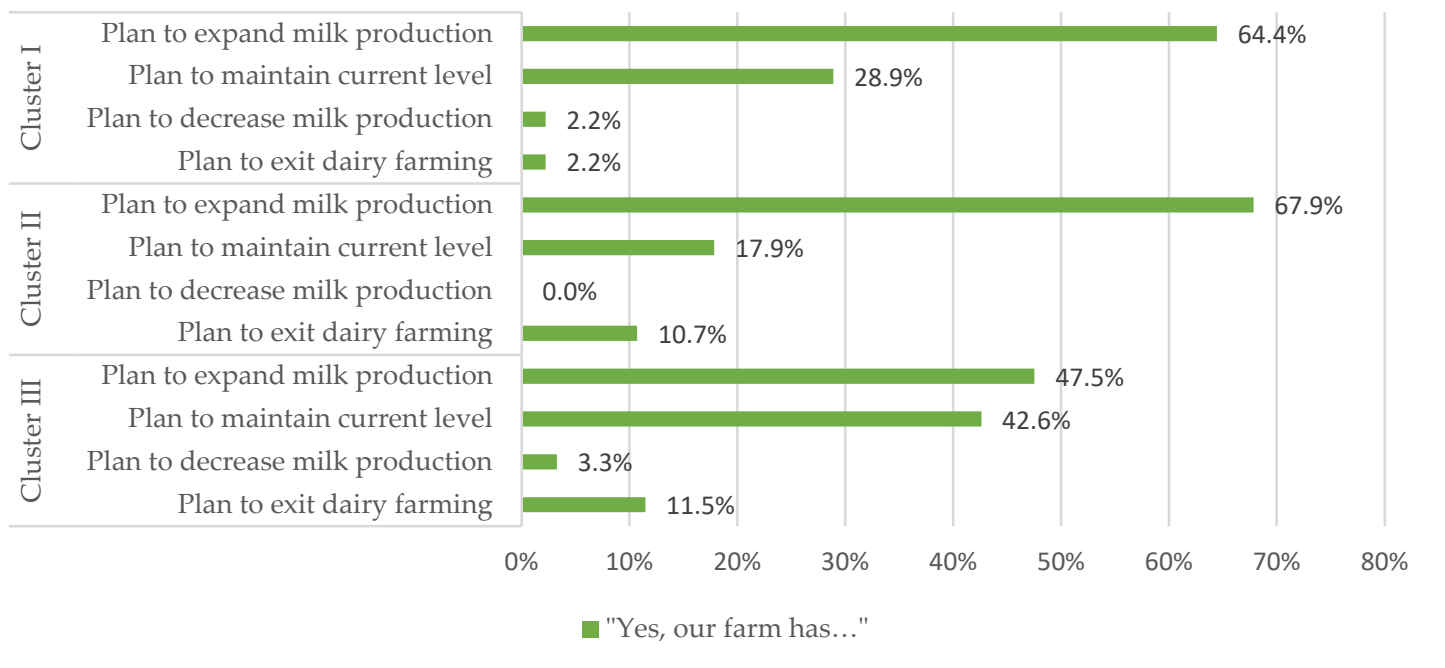

Figure 4. Share (\%) of farmers responding, "yes" to following questions: "Our farm has plan to expand milk production (yes/no)", "Our farm has plan to maintain current milk production level (yes/no)", "Our farm has plan to decrease milk production (yes/no)", and "Our farm plan to exit milk production (yes/no)". Missing three observations in Cluster I and missing one observation in Clusters II and III.

The respondents replied to the question on their existing farm management vision and business plan: "Our farm has a vision and written business plan (yes/no)" (Figure 2). Regarding the vision, the existence of a vision differentiates between the clusters more strongly than the existence of the business plan. As much as $30 \%$ of the farmers in Cluster I had figured out a vision for their business, compared to $28 \%$ in Cluster III and only $13 \%$ in Cluster II. Therefore, generally positive (Cluster I) and generally negative (Cluster III) positions on the megatrends were associated with the existence of a vision, whereas the lack of a vision (Cluster II) was associated with varying positions on specific megatrends. A similar pattern regarding the lower uptake of business plans exists: only $7 \%$ of farmers in Cluster II had a business plan, compared to $11-13 \%$ in Clusters I and III.

Regarding the management goals, the dairy farmers had varying specifications of goals and monitoring tools in use: goals for farm economics, labor productivity, and production as well as key performance indicators (KPIs) (Figure 3). KPIs indicate the daily management values of the milk production. Level of milk production is measured with annual average milk yield per cow and this value is compared across farms. Annual average milk yield measure implicates the quality of the herd, farming conditions, and overall herd management. Among the three clusters, farmers in Cluster I had the lowest adoption rates for KPIs and the highest adoption rates of goals for farm economics and labor productivity. Thus, their competitive edge and positive view on the megatrends is based on economic considerations.

Farmers in Cluster II have the highest adoption rate of KPIs but the lowest adoption rates for farm economics and production related goals. This refers to an orientation where productivity as well as measurement of success and benchmarking are important. This might partly explain the mixed estimates of the impacts of specific megatrends: some are considered beneficial while some others are not.

Farmers in Cluster III had the highest adoption rate of production related goals and, clearly, the lowest adoption rate for labor productivity goals. This refers to a "traditional" producer identity, with a strong focus on production volumes rather than on productivity or profitability. Farmers in this group had generally negative assessments of the impacts of the megatrends on their businesses and the shortest futures orientation. 
The farmers were also asked for their plans for the future direction of their farm business: to exit dairy farming, to decrease milk production, to maintain the current level of milk production or to expand milk production (Figure 4). The profiles of the three clusters were again rather different. The most distinctive difference was found between Cluster III and the other clusters. Farmers in Cluster III were clearly most often planning to maintain the current level of milk production, to decrease production, or to exit dairy farming. This downturn in dairy business was associated with a strong emphasis on production related goals and with a generally negative assessment of the impacts of the megatrends. Farmers in Cluster II were planning to expand milk production more often than farmers in the other clusters, whereas plans to (just) maintain or to decrease production were most rare in this cluster. These growth oriented farmers were relying on productivity measurement and had mixed estimates of the impacts of megatrends. Farmers in Cluster I took in between positions in most indicators; none of the options was most common and only the plan to exit dairy farming was most rare in this group. In this respect, Cluster I is the most stable group.

\subsection{Farmers' Values and Futures Consciousness}

To understand more deeply farmers' values and relationship to future, we used a 5-point Likert-scale (fully disagree ... fully agree) with several claims related to futures consciousness and futures orientation (Table 5). This dimension was explored with 15 claims related to the attitudes and activities related to the futures domain. Table 5 presents the mean values of the three clusters. The profiles of the clusters are strikingly different. Farmers in Cluster I were characterized by extensive future work: they were interested in alternative futures and they investigated what might happen in the business environment. They looked at their own business from the outside in: how alternative futures framed their business. This setting might partly explain why farmers in Cluster I perceived the megatrends positively: they knew what these were all about. Farmers in Cluster II were evaluators who mirrored their business against other farmers and existing scenarios. They looked at the futures from the inside out: how their business might survive in alternative futures. This setting might partly explain why specific megatrends appeared positive and some others appeared negative. Their management style was based on measurement and benchmarking and this style is related to their futures orientation as well. Finally, farmers in Cluster III had more or less outsourced futures work: they were uninterested in or even afraid of thinking about the alternative futures and relied on experts and advisors. This is in line with their generally negative perception of most megatrends.

Further on, there were differences in the farm management focuses and practices between the clusters (Table 6). Farmers in Cluster I were characterized by a reliance on knowledge and technology. They were well organized and had well analyzed positions on alternative futures and megatrends and their business was running well. Farmers in Cluster II focused intensively on existing business and, among the three groups of farmers, these farmers were most tight to their farm, their animals, their milk production, and the whole milk sector. These farmers aimed at continuing farming and milk production with a growth strategy. Some of the megatrends were considered positive, some negative. Finally, farmers in Cluster III avoided risks and focused on production volumes. These were "traditional" farmers with production related goals and, frequently, a plan to decrease milk production or to give up dairy production. Most megatrends were considered to have a negative impact by these farmers. 
Table 5. Question: "How well the following claims fit to your actions?" Responses with a 5-point Likert-scale. Cluster mean values are presented in the table.

\begin{tabular}{|c|c|c|c|}
\hline Claim & Cluster I & Cluster II & Cluster III \\
\hline I discuss milk production in the future with other farmers & 4.24 & 4.25 & 3.95 \\
\hline I am familiar with agricultural futures scenarios & 4.00 & 4.07 & 3.89 \\
\hline I have attended futures focused events & 3.40 & 3.36 & 3.25 \\
\hline I have a positive attitude toward the future & 3.89 & 3.71 & 3.30 \\
\hline $\begin{array}{l}\text { Occasionally, I envision the business environment in the } \\
\text { coming } 10 \text { years' time }\end{array}$ & 4.09 & 4.46 & 4.13 \\
\hline I am uninterested in the future & 1.58 & 1.46 & 1.69 \\
\hline I am afraid of thinking about the future & 2.40 & 2.61 & 2.75 \\
\hline $\begin{array}{l}\text { I base my understanding of the changes in the business } \\
\text { environment on the experts' evaluations }\end{array}$ & 2.98 & 3.29 & 3.28 \\
\hline $\begin{array}{l}\text { I base my understanding of the business environment } \\
\text { changes on my own judgement }\end{array}$ & 3.96 & 3.82 & 3.87 \\
\hline $\begin{array}{l}\text { I regularly evaluate the farm business situation and } \\
\text { future actions }\end{array}$ & 4.00 & 4.07 & 3.82 \\
\hline $\begin{array}{l}\text { In my opinion, business environment change evaluation } \\
\text { is part of risk management }\end{array}$ & 4.47 & 4.39 & 4.16 \\
\hline $\begin{array}{l}\text { I adapt my farm business management to the changes in } \\
\text { the business environment }\end{array}$ & 4.33 & 4.25 & 4.13 \\
\hline I have composed alternative scenarios for my farm & 3.47 & 3.46 & 3.46 \\
\hline I base important decisions on the available knowledge & 4.20 & 4.00 & 4.05 \\
\hline I discuss farm management options with advisors & 3.02 & 3.39 & 3.41 \\
\hline
\end{tabular}

Note: highest values on bold.

Table 6. Question: "How important the following subjects are in the milk production?" Responses with a 5-point Likert-scale, mean values are presented in the table.

\begin{tabular}{lccc}
\hline Claim & Cluster I & Cluster II & Cluster III \\
\hline Working with animals and nature & 4.33 & 4.43 & 4.11 \\
Expansion of milk production & 3.56 & $\mathbf{3 . 6 1}$ & 3.46 \\
Clean working environment & 3.98 & $\mathbf{4 . 3 6}$ & 4.13 \\
Development of own expertise & 4.31 & 4.36 & 4.20 \\
Inspection of the milk production reports & 3.98 & 4.07 & $\mathbf{4 . 1 0}$ \\
Utilizing diverse technologies & 3.93 & 3.75 & 3.72 \\
Reacting to the changes in the business environment & 3.96 & 4.18 & 3.92 \\
Avoiding economic risk in milk production & 3.44 & 3.50 & 3.66 \\
Inspection of the economic results of milk production & 4.31 & $\mathbf{4 . 5 7}$ & 4.56 \\
Smooth work practices & 4.58 & 4.50 & 4.44 \\
Continuing the family farm & 3.02 & 3.50 & 3.11 \\
Maintaining current production level & 3.71 & 3.39 & 3.71 \\
Developing Finnish milk production & 3.89 & $\mathbf{4 . 0 7}$ & 3.89 \\
Anticipation of the producer prices & 3.69 & $\mathbf{4 . 1 1}$ & 4.05 \\
Acting according to ecological values & 3.60 & $\mathbf{3 . 7 5}$ & 3.56 \\
Working environment that eases workflow & 4.53 & $\mathbf{4 . 5 4}$ & 4.46 \\
Efficient production practices & 4.31 & $\mathbf{4 . 3 2}$ & 4.11 \\
Anticipation of the input prices & 4.09 & $\mathbf{4 . 1 1}$ & 4.08 \\
Usage of the best possible information in & 4.38 & 4.14 & 4.16 \\
decision-making & 3.13 & $\mathbf{3 . 2 9}$ & 2.85 \\
Business success with growing risk & & & \\
\hline Note: & &
\end{tabular}

Note: highest values on bold.

\section{Discussion}

The aim of this study was to increase understanding of how Finnish dairy farmers assess the impact of selected megatrends on their business during the ten next years. Observing a turbulent operating environment, futures consciousness, and the ability to evaluate developments in the business environment are crucial for the business survival. Additionally, farmer specific issues, such as age, do influence the potential career as a dairy 
farmer and managerial actions. However, competitive farm units are often sold to the subsequent generation. Then, thorough evaluation of megatrends and other change drivers becomes even more important on a farm level.

Statistical analysis of the assessments of the impacts of the megatrends resulted in three clusters of farmers which were profiled regarding the visions, goals, and plans for the future, as well their futures and management orientations. Demographic or structural factors, such as age, education, or farm size, did not differentiate the clusters. In Ireland, O'Donnel et al. [47] found that the number of milking cows was not a significant factor in explaining farmers' aims to continue dairy farming. However, differences between the clusters were found in the orientation to farm management. In this regard, the results are similar to those reported by Westbrook and Nuthall [48], who emphasized the role of farmers' personal characteristics.

Next, a brief description of the profiles of the three clusters will be provided. Cluster I represents goal oriented farmers, Cluster II represents analytical farmers and Cluster III represents production orientated farmers. The positive (Cluster I), varying (Cluster II) or negative (Cluster III) assessments of the impacts of the megatrends seemed to have a logical association with specific behavioral factors that characterized farmers in each cluster. However, clustering has limitations, as Westbrook and Nuthall [48] emphasize; there are farms that can be located in two or more clusters, depending on the perspective of the research.

\subsection{Cluster I, Goal Oriented Farmers}

Farmers in Cluster I composed a profile with a growth-orientation and positive attitude toward the future with openness to alternatives. Dairy farmers in Cluster I had a positive anticipation of their future and a strong confidence in their own capabilities to access the information and knowledge necessary for decision-making. They emphasized the evaluation of the business environment in their management orientation and seemed to be willing to adjust their business actions due to the changes in the operating environment. These farmers were committed to dairy farming and they sought a better position in the farming business. Surprisingly, these farmers had the smallest farms in the sample. This indicates that personal, rather than structural, factors play a role in the strategic commitments. Especially, a strong interest and focus on the futures supports this setting, by reducing uncertainty. Focusing on and following only milk production was not a primary action for these farmers, but their focus was much broader. As many as two thirds of these farmers had a vision for the farm.

Megatrends related to digitalization and technological development were resources for the dairy farmers in Cluster I to build a future in the dairy farming business field. Marescotti et al. [49] studied Italian mountain region dairy farmers' relationship to smart farming technologies and found three clusters, one of which was keen on technological development. These farmers had positive expectations for their farm development, which was somewhat similar to the farmers in Cluster I [49]. Cluster I farmers also assessed climate change quite positively. Climate change is commonly considered to be a threat and a complex phenomenon [50]. Hyland et al. [3] reported that livestock farmers could have a very foggy vision of the possibilities and opportunities offered by climate change. Contrary to these results, ref. [50] also found a group of farmers who had positive expectations toward the impacts of climate change on the farm business, although most farmers in their study had negative or neutral expectations.

Aside from the positive orientation toward the future, the farmers in Cluster I are the most goal oriented group of farmers. While setting goals for farm labor was not appealing in other clusters, for this group of farmers it provided information of the amount of "fixed costs per unit of production" (p. 92, [51]). Dairy farming can be more or less labor intensive depending on the choices made regarding management, organization and investments. While the farms are aiming to survive in a complex environment where major change drivers challenge business operators, cost efficiency is an important factor in farm 
management. Through maintaining the cost efficiency and competitiveness of the farm business and simultaneously being proactive concerning future evaluation, these farmers build adaptability capacity for a long range period.

\subsection{Cluster II, Analytical Farmers}

The profile of the second cluster was outlined as an analytical mindset, combining high milk production level and thorough business evaluation. These farmers collected information from various sources. These analytical farmers anticipated some specific megatrends, such as urbanization, globalization, and climate change, to have a positive influence on their farm businesses. Urbanization and job opportunities in the cities promote structural change. Structural change promotes farm growth when small farms will close their business and release land for the growing farms, e.g., [52]. Furthermore, globalization opens markets for a wider product range. As Finnish cattle husbandry is based on grass silage [53] and only a mandatory and minimal amount of antibiotics is used for medication [54], Finnish dairy products can constitute high-quality niche products in global markets. Globalization also offers access to affordable resources when logistics costs are low and trade barriers do not exist [55]. These resources include production inputs, machinery, knowledge, and labor. While the dairy farmers confront global competition, globalization as a change driver has increased pressure to expand farms and to produce milk more efficiently [56]. As globalization may feel distant, the analytical farmers can identify the impacts of globalization on farm level business management.

Cluster II farmers had a strong focus on milk production, productivity, and maintenance of the capacity to continue the chosen business model in the future. They evaluated different megatrends to have distinct kinds of impacts on their businesses: some positive, some negative. They aimed to make justified decisions and were determined to develop their own capacity in the dairy farm business. Bolisani and Bratianu [57] emphasized knowledge management as an important factor in a business strategy with long range planning periods.

Regarding the farm management focus, farmers in this cluster appeared to thoroughly evaluate the choices they make and to assess the inputs they used in milk production. These farmers were determined to maintain the chosen business model and to develop dairy farming further. Determined farmers are found in other studies too, e.g., by Veerhees et al. [58], who found several strategic orientations among dairy farmers in Lithuania, Poland, and Slovenia.

\subsection{Cluster III, Production Oriented Farmers}

Farmers in Cluster III had two distinctive features: a strong production orientation and a negative assessment of all megatrends. Farmers in this cluster reached the highest annual average milk yield and high milk yield is a manifestation of a high production orientation. Additionally, these farmers had the largest herds. Still, their future prospects were negative. These farmers were not small scale or traditional dairy farmers—on the contrary. This result could arise from the worries caused by expansion investments. These investments bound the farmers to continue existing production, irrespective of trends or other potential change drivers in a turbulent and uncertain business environment. Most farmers in this group were not looking for growth, which hints to the same mindset.

Dairy farmers in this cluster seemed to emphasize high milk yield, which is a traditional measure on dairy farms. Continuous improvement of milk production underlines the traditional conception of modern and intensive agriculture, where large production units with high yields are stand poles for efficient farming [56]. As these farmers were deeply focused on the milk production, they could consider futures thinking as an overwhelming task that is causing more pressure, rather than giving new motivation for the milk production. Production-orientation can also be a chosen strategy, as many farmers rely on three factors to build a successful dairy farm: the farmer, the productivity of farming, and the external business environment of farming [58]. Hyland et al. [3] suggested that 
production oriented farmers tend to emphasize keeping the farm business running with a profitable level more than looking for the possibilities provided by climate changes, one of the megatrends at hand.

Evaluation of the impacts of the megatrends could be unfamiliar for farmers who have a strong focus on the farm production. Relatedly, farmers in this group relied significantly on external experts. These farmers assessed all megatrends to have a negative impact on their business, including digitalization and technological development. This result differs from the findings by [49], who found the largest farms in their study to have the most positive expectation of smart farming technologies, which are manifestations of digitalization and technological development.

\section{Conclusions}

This paper aimed to understand how a sample of Finnish dairy farmers assesses the impact of global change drivers, specifically, eight megatrends, on their farming businesses in the next ten years. This paper provides a wide perspective on the nexus of farmers' futures consciousness and business management, which goes beyond a single change driver, such as climate change, globalization, or digitalization.

Three clusters emerged in the study: goal oriented farmers (Cluster I), analytical farmers (Cluster II) and production oriented farmers (Cluster III). Behavioral factors differentiated these farmer groups more strongly than demographic or structural factors. Goal oriented farmers (Cluster I) had visions, several goals, and they were committed to diversified futures work to find ways to continue or expand the business-there were hardly any plans to give up the dairy farming business in this group. These farmers clearly benefit from the capacity to assess futures and they could share their skills with other farmers in peer networks. Analytical farmers (Cluster II) followed performance indicators and regularly evaluated possibilities for enlargement through many methods, channels, and networks. However, their scope was narrower than that of Cluster I farmers and these farmers could benefit from the better futures skills that could be provided by Cluster I farmers, educational institutions, or business advisors. Finally, production related goals and indicators were dominant among the production oriented farmers (Cluster III), who were uninterested or afraid of the future which was expected to be described by experts and advisors. Plans to exit dairy farming were most common in this group, but still, most farmers were planning to continue with their quite large farms. This group of farmers could possibly benefit most from futures skills, which would expand their horizon beyond the own farm. Despite the small sample size, the exposed three clusters profiling the futures and management orientations of farmers were consistent and in line with the results in other studies. More studies are needed that combine farm management and the futures consciousness of the farmers. The complementary knowledge produced by this study may assist in the provision of targeted education, counselling, and policy measures for the farmers. This survey was made before COVID-19 pandemic. While there has been a vast amount of discussion on how this pandemic will change the world and world economy, it would be interesting to replicate this research in the coming years to see if the results would be similar.

Author Contributions: Conceptualization, L.-K.S. and K.T.; methodology, L.-K.S.; validation, L.-K.S. and K.T.; formal analysis, L.-K.S.; data resources, L.-K.S.; writing—original draft preparation, L.-K.S.; writing - review and editing, L.-K.S. and K.T.; visualization, L.-K.S. and K.T. All authors have read and agreed to the published version of the manuscript.

Funding: The contributing author was funded by the Oiva Kuusisto Foundation (Finland). Open access funding provided by University of Helsinki.

Institutional Review Board Statement: Not applicable.

Informed Consent Statement: Not applicable. 
Data Availability Statement: Restrictions apply to the availability of these data. Further use of the data is not agreed among the respondents.

Acknowledgments: Open access funding provided by University of Helsinki.

Conflicts of Interest: The authors declare no conflict of interest. The funders had no role in the design of the study; in the collection, analyses, or interpretation of data; in the writing of the manuscript, or in the decision to publish the results.

\section{References}

1. Barnes, A.; Sutherland, L.-A.; Toma, L.; Matthews, K.; Thomson, S. The effect of the Common Agricultural Policy reforms on intentions towards food production: Evidence from livestock farmers. Land Use Policy 2016, 50, 548-558. [CrossRef]

2. Poczta, W.; Średzińska, J.; Chenczke, M. Economic Situation of Dairy Farms in Identified Clusters of European Union Countries Agriculture 2020, 10, 92. [CrossRef]

3. Hyland, J.J.; Jones, D.L.; Parkhill, K.A.; Barnes, A.P.; Williams, A.P. Farmers' perceptions of climate change: Identifying types. Agric. Hum. Values 2016, 33, 323-339. [CrossRef]

4. Tisch, D.; Galbreath, J. Building organizational resilience through sensemaking: The case of climate change and extreme weather events. Bus. Strategy Environ. 2018, 27, 1197-1208. [CrossRef]

5. Nuthall, P.L. Determining the important management skill competencies. Agric. Syst. 2006, 88, 429-450. [CrossRef]

6. Dukeshire, S.; Masakure, O.; Mendoza, J.; Holmes, B.; Murray, N. Understanding consumer choices for Ontario produce. Renew. Agric. Food Syst. 2015, 30, 439-449. [CrossRef]

7. Boogaard, B.K. Sociocultural sustainability of livestock farming: An inquiry into social perceptions of dairy farming. Animal 2011, 5, 1458-1466. [CrossRef]

8. Pouru, L.; Dufva, M.; Niinisalo, T. Creating organisational futures knowledge in Finnish companies. Technol. Forecast. Soc. Chang. 2019, 140, 84-91. [CrossRef]

9. Martin, G.; Magne, M.-A.; Cristobal, M.S. An Integrated Method to Analyze Farm Vulnerability to Climatic and Economic Variability According to Farm Configurations and Farmers' Adaptations. Front. Plant Sci. 2017, 8, 1483. [CrossRef]

10. Richtnér, A.; Löfsten, H. Managing in turbulence: How the capacity for resilience influences creativity. RD Manag. 2014, 44, 137-151. [CrossRef]

11. Hadley, G.L.; Harsh, S.B.; Wolf, C.A. Managerial and Financial Implications of Major Dairy Farm Expansions in Michigan and Wisconsin. J. Dairy Sci. 2002, 85, 2053-2064. [CrossRef]

12. Methorst, R.G.R.; Roep, D.D.; Verhees, F.J.H.M.F.; Verstegen, J.A.A.M. Differences in farmers' perception of opportunities for farm development. NJAS-Wagening. J. Life Sci. 2017, 81, 9-18. [CrossRef]

13. Zimmermann, A.; Heckelei, T. Structural Change of European Dairy Farms-A Cross-Regional Analysis. J. Agric. Econ. 2012, 63, 576-603. [CrossRef]

14. Poli, R. Introduction to Anticipation Studies; Springer: Cham, Switzerland, 2017. [CrossRef]

15. Vecchiato, R. Strategic planning and organizational flexibility in turbulent environments. Foresight 2015, 17, 257-273. [CrossRef]

16. McBride, W.D.; Johnson, J.D. Defining and Characterizing Approaches to Farm Management. J. Agric. Appl. Econ. 2006, 38, 155-167. [CrossRef]

17. Ondersteijn, C.J.M.; Giesen, G.W.J.; Huirne, R.B.M. Perceived environmental uncertainty in Dutch dairy farming: The effect of external farm context on strategic choice. Agric. Syst. 2006, 88, 205-226. [CrossRef]

18. Hansson, H. Strategy factors as drivers and restraints on dairy farm performance: Evidence from Sweden. Agric. Syst. 2007, 94, 726-737. [CrossRef]

19. Peltonen-Sainio, P.; Niemi, J.K. View of Protein Crop Production at the Northern Margin of Farming: To Boost or Not to Boost. Agric. Food Sci. 2012, 21, 370-383. [CrossRef]

20. Gebbers, R.; Adamchuk, V.I. Precision agriculture and food security. Science 2010, 327, 828-831. [CrossRef]

21. Bryant, C.R. Entrepreneurs in the rural environment. J. Rural. Studies 1989, 5, 337-348. [CrossRef]

22. Lombardo, T. Future Consciousness. World Futures Rev. 2016, 8, 116-140. [CrossRef]

23. Sharpe, B.; Hodgson, A. Anticipation in three horizons. In Handbook of Anticipation; Poli, R., Ed.; Springer International Publishing: Cham, Switzerland, 2019; pp. 1-18.

24. Ahvenharju, S.; Minkkinen, M.; Lalot, F. The five dimensions of Futures Consciousness. Futures 2018, 104, 1-13. [CrossRef]

25. Sarpong, D.; Eyres, E.; Batsakis, G. Narrating the future: A distentive capability approach to strategic foresight. Technol. Forecast. Soc. Chang. 2019, 140, 105-114. [CrossRef]

26. Reidsma, P.; Frank, A.E.; Ae, E.; Oude, A.; Ae, L.; Leemans, R. Vulnerability and adaptation of European farmers: A multi-level analysis of yield and income responses to climate variability. Reg. Environ. Chang. 2009, 9, 25-40. [CrossRef]

27. Nicholas, K.A.; Durham, W.H. Farm-scale adaptation and vulnerability to environmental stresses: Insights from winegrowing in Northern California. Glob. Environ. Chang. 2012, 22, 483-494. [CrossRef]

28. e Cunha, M.P.; Palma, P.; da Costa, N.G. Fear of foresight: Knowledge and ignorance in organizational foresight. Futures 2006, 38, 942-955. [CrossRef] 
29. Teigen, K.H.; Brun, W. Anticipating the future. Appraising risk and uncertainty. In Decision Making. Cognitive Models and Explanations; Crozier, R., Ranyard, R., Svenson, O., Eds.; Routledge: London, UK; New York, NY, USA, 1997 ; pp. 112-127.

30. Natural Resources Institute Finland. Statistics Database; Natural Resources Institute Finland: Helsinki, Finland, 2021.

31. Abeni, F.; Petrera, F.; Galli, A. A Survey of Italian Dairy Farmers' Propensity for Precision Livestock Farming Tools. Animals 2019, 9, 202. [CrossRef]

32. Gardezi, M.; Arbuckle, J.G. Techno-Optimism and Farmers' Attitudes toward Climate Change Adaptation. Environ. Behav. 2020, 52, 82-105. [CrossRef]

33. Hillmann, J.; Duchek, S.; Meyr, J.; Guenther, E. Educating Future Managers for Developing Resilient Organizations: The Role of Scenario Planning. J. Manag. Educ. 2018, 42, 461-495. [CrossRef]

34. IPCC. Technical summary. In Climate Change 2013-The Physical Science Basis; Cambridge University Press: Cambridge, UK, 2014. [CrossRef]

35. Pelling, M. Adaptation to Climate Change: From Resilience to Transformation; Taylor \& Francis Group: Abingdon, UK, 2011.

36. OECD. OECD Science, Technology and Innovation Outlook 2016; The Organisation for Economic Co-Operation and Development: Paris, France, 2016.

37. Fleischmann, A.; Oppl, S.; Schmidt, W.; Stary, C. Contextual Process Digitalization Changing Perspectives—Design Thinking—Value-Led Design, 1st ed.; Springer International Publishing: Cham, Switzerland, 2020.

38. EuroStat. Patterns of urban and city developments. In Urban Europe-Statistics on Cities, Towns and Suburbs; European Union: Luxembourg, 2016; pp. 56-83. [CrossRef]

39. OECD. Measuring Globalisation: OECD Economic Globalisation Indicators 2010, 2nd ed.; OECD The Organisation for Economic Co-Operation and Development: Paris, France, 2010.

40. Sieranoja, S. Clustering with kNN Graph and k-Means. Ph.D. Thesis, University of Eastern Finland, Joensuu, Finland, 2020. No 401.

41. Distefano, C.; Mindrila, D. Cluster analysis. In Handbook of Quantitative Methods for Educational Research; Teo, T., Ed.; Sense Publishers: Rotterdam, The Netherlands, 2013.

42. Cleff, T. Exploratory Data Analysis in Business and Economics; Springer: Berlin/Heidelberg, Germany, 2014.

43. King, R.S. Cluster Analysis and Data Mining: An Introduction; Mercury Learning and Information: Dulles, VA, USA, 2015.

44. Salkind, N.J. Encyclopedia of Research Design; Sage: Thousands Oaks, CA, USA, 2010.

45. Field, A. Discovering Statistics Using IBM SPSS Statistics, 5th ed.; Sage Edge: Los Angeles, CA, USA, 2018.

46. Geher, G.; Hall, S. Straightforward Statistics : Understanding the Tools of Research; Oxford University Press: New York, NY, USA, 2014.

47. O'Donnel, S.; Horan, B.; Butler, A.M.; Shalloo, L. A survey of the factors affecting the future intentions of Irish dairy farmers. J. Agric. Sci. 2011, 149, 647-654. [CrossRef]

48. Wesbrook, V.; Nuthall, P. Why small farms persis? The influence of farmers' characters on farm growth and development. The case of smaller dairy farmers in NZ. Aust. J. Agric. Reseouce Econ. 2017, 61, 663-684. [CrossRef]

49. Masrescotti, M.E.; Demartini, E.; Filippini, R.; Gaviglio, A. Smart farming on mountain areas: Investingating livestock farmers' technophobia and tehcnophilia and their perception of innovation. J. Rural Stud. 2021, 86, 463-472. [CrossRef]

50. Barnes, A.P.; Toma, L. A typology of dairy farmer perceptions towards climate change. Clim. Chang. 2012, 112, 507-522. [CrossRef]

51. Samson, G.S.; Gardebroek, C.; Jongeneel, R.A. Explaining production expansion decisions of Dutch dairy farmers. NJASWagening. J. Life Sci. 2016, 76, 87-98. [CrossRef]

52. Forbord, M.; Bjørkhaug, H.; Burton, R.J.F. Drivers of change in Norwegian agricultural land control and the emergence of rental farming. J. Rural Stud. 2014, 33, 9-19. [CrossRef]

53. Huhtanen, P.; Jaakkola, S.; Nousiainen, J. An oveview of Silage Research in Finland: From Ensiling Innovation to Advances in Dairy Cow Feeding. Agric. Food Sci. 2013, 22, 35-56. [CrossRef]

54. Espetvedt, M.N.; Rintakoski, S.; Wolff, C.; Lind, A.K.; Lindberg, A.; Virtala, A.M.K. Nordic veterinarians' threshold for medical treatment of dairy cows, influence on disease recording and medicine use: Mild clinical mastitis as an example. Prev. Vet. Med. 2013, 112, 76-89. [CrossRef]

55. Bradford, S.C.; Lawrence, R.Z. Has Globalization Gone Far Enough? The Costs of Fragmented International Markets; Peterson Institute for International Economics: Washington, DC, USA, 2004.

56. Clay, N.; Garnett, T.; Lorimer, J. Dairy intensification: Drivers, impacts and alternatives. Ambio 2020, 49, 35-48. [CrossRef]

57. Bolisani, E.; Bratianu, C. Knowledge strategy planning: An integrated approach to manage uncertainty, turbulence, and dynamics. J. Knowl. Manag. 2017, 21, 233-253. [CrossRef]

58. Verhees, F.; Malak-Rawlikowska, A.; Stalgiene, A.; Kuipers, A.; Klopčič, M. Dairy farmers' business strategies in Central and Eastern Europe based on evidence from Lithuania, Poland and Slovenia. Ital. J. Anim. Sci. 2018, 17, 755-766. [CrossRef] 